\title{
Analysis on the Comparison Between Chinese and Western Classroom Teaching
}

\begin{abstract}
Yuan $\mathrm{He}^{1}$
${ }^{1}$ Jiangsu University, Jiangsu 212013, China

*Corresponding author. Email: 1004853415@qq.com

ABSTRACT

Education is the foundation of a hundred years' plan. Due to the different historical and cultural traditions and social backgrounds, Chinese and Western education have huge differences in concepts, thinking patterns, teaching methods and ways of communicating with parents, etc. As the most fundamental means of education teaching, classroom teaching is still the main way to impart knowledge and personnel training, and the classroom teaching implementation will directly affect the teaching effect. Western feasible teaching mode has important meaning to achieve the teaching goal through comparing. This article firstly discusses about the present situation of Chinese and western classroom teaching, then compares their respective characteristics of two kinds of teaching methods. Through the analysis on two different teaching modes of the teaching effect and its influence, teachers do well in selecting teaching ways from each other, complementing each other, further strengthen the existing classroom teaching reform, so as to better promote the development of education.
\end{abstract}

Keywords: Teaching methods, Classroom teaching, Comparison of Chinese and western

\section{INTRODUCTION}

With the development of economy and society, exchange activities between China and the West in various fields are becoming more and more frequent. China's development has unprecedented vitality and vigor, and there are more and more opportunities for learning and exchanging between China and foreign countries. Such as exchange students' study, foreign education and culture exhibition, etc. However, due to the constraints of different educational systems, teaching concepts and teaching models, the differences between Chinese and Western classroom teaching are increasingly prominent, and contradictions and problems also appear. Therefore, it is necessary to think and study the differences between Chinese and Western teaching.

\subsection{Thinking Mode and Educational Mode}

First of all, the guiding ideology of traditional Chinese education is "the dignity of teachers", "a teacher for a day and a father for life" [1]. Teachers are condescending, sacrosanct and have absolute authority, while the western education model focuses on the equality between teachers and students. Chinese education attaches more importance to the construction of students' basic knowledge than the cultivation of their creativity. The main purpose of students' education is to increase their knowledge. This can be seen in the BBC documentary Chinese Education. In China, educators believe that the formation of creativity is a slow process that depends on solid basic knowledge, so it takes a long time to consolidate the basic knowledge. In the West, students are taught to learn independently, ask questions, think critically, form a sense of independence, and challenge knowledge. The purpose of education is to seek higher-level cognitive learning. In the West, it is illegal for educational institutions to publish students' academic results, but in China, it is quite common to publish students' academic performance, because it is considered to motivate the poor students to learn from the excellent students and actively seek for progress.

Besides, western education focuses on cultivating students' ability to think independently and solve problems, so as to cultivate students' ability to live in the society and make preparations for entering the society in advance [2]. In our country, school education attaches great importance to the cultural basic courses, students mainly study Chinese, math and science courses, and school of management is strict, asking the students to concentrate in class and inherit the fine traditions in the 
education teaching idea, knowledge, standardized behavior has certain positive role, etc.

\subsection{The Current Situation of Classroom Teaching in China and West}

There are three main methods of classroom teaching: teacher-centered classroom teaching; student-centered classroom discussion; classroom teaching in which teachers and students integrate.

Under the background of traditional exam-oriented education, teaching methods of Chinese teachers are mainly traditional. The main means are teaching materials and PPT presentation [3]. Teachers focus on the teaching theme, step by step, layer by layer, and have clear learning requirements for each part. When teachers introduce concepts and theory, they often pay attention to tight logic and have coherence and a sense of wholeness. At the end of each course, homework should be assigned and textbooks and reference books should be recommended to help students complete their learning tasks. Students are required to complete the pre-class preview, class notes, after-class exercises and other links of training. The teacher repeatedly explains and trains the subjects so that the students can pass the exam successfully, which makes the students can't think for themselves and passively accept the knowledge. The process of accepting the knowledge is relatively easy, but the students in the class do not have enough time to think independently. Over time, students have little ability to ask more profound questions than what teachers teach them. It is difficult to cultivate students' independent learning ability of thinking and innovating. Thus, the knowledg acquired is difficult to be applied flexibly in practical work. This knowledge is useless when it is needed.

In the Western classroom, discussion is the main teaching method. In addition to using the teaching method, teachers also make full use of Q\&A, group work, reading report, social investigation, practice, experimental teaching and other methods, as far as the art of education is concerned. In addition to the traditional blackboard writing, slide show and projection infrastructure, modern information technology has also been adopted by teachers. In the first lesson, teachers should give students their E-mail address so that teachers and students can communicate with each other better after the class. In English classes, for example, students are required to read closely-related chapters in the main textbook and other supporting readings before each class. The teacher simply introduces the main points in class, without a lot of detailed explanation to let the students read and think more. The teacher asks questions about specific teaching contents for group discussion, assigns cases to be studied by the group, or assigns the group to report the homework assigned in the last class. There are more exchanges between teachers and students in the classroom. So the classroom atmosphere is often more active. At the end of each lesson, the teacher should assign the literature that the student reads emphatically according to the teaching content of the next class. It is this connecting link arrangement that makes students well prepared in class. Teachers and students all hope to solve all kinds of problems through classroom teaching to make teaching productive.

\subsection{Chinese and Western Classroom Teaching Effect}

Chinese classroom teaching not only has a large capacity of knowledge, but higher characteristics are also required for students. Moreover, in the teaching of rigor, seriousness are impeccable in the knowledge to the students to lay a solid foundation system, also cultivate the student certain self-study ability [4]. The statistics show that the Chinese students are at the top in all kinds of competitions. These all explain that under the teachercentered teaching mode in China, students have solid basic knowledge, clear learning objectives and other advantages. It is these advantages that make the ability of Chinese people in some professional jobs widely recognized in the world.

However, this teacher-centered teaching method also has many disadvantages. As a result, students are only used to passively receiving knowledge. They are not good at asking questions and lack the ability to think further. Students are accustomed to relying too much on teachers and textbooks in their study. The ability of independent learning is poor. For example, the classroom atmosphere is not active. The teacher talks too much, the students think too little and move too little. The students are good at memorizing, but poor at presentation and hands-on skills. At the same time, most obviously, it also causes students not to read widely to solve a difficult problem. Chinese students' practical operation level and application ability are relatively poor.

Western teaching methods adopt the student-centered teaching method. Classroom teaching forms such as oneon-one or questioning dialogue and discussion stimulate students' inquiring nature and enable students to learn to cooperate in dialogue and discussion, and learn to listen to others and express their own opinions to make critical thinking and creative thinking thrive. Teachers often provide students with opportunities to observe, compare and analyze the same problem from different perspectives, which doesn't require a standard answer. The students not only deepen their understanding of the problem, but also acquire a lot of knowledge and improve their cognitive abilities. In class, teachers give students enough time to express their opinions and inspire them to put forward their own ideas and finally by the old teachers and students together to sum up. In this way, students are more impressed by their study, but also increase the interest of learning. In addition, western students are 
relatively flexible in learning and have more extracurricular activities after entering the society [5]. In western classrooms, teachers give students plenty of time to think, give them enough space to develop a vision, give them ample opportunity to raise questions, and give students the freedom to solve problems themselves. Therefore, students' self-learning ability and access to information can be improved by using data for project research and carrying out social practice. The ability of doing things by oneself is relatively strong.

But more casual and looser classroom teaching in the West also has its own problems. The teaching content lacks rigor, and the classroom teaching content is simple and has low requirements, so the basic knowledge of Western students is not solid enough. Some students leave school without basic reading and numeracy skills. In addition, teachers give students more freedom in classroom teaching. Some students are also easy being undisciplined, and develop some bad habits. In a lot of professional games, western performance often lags behind that of Chinese students.

\subsection{Implications of the Differences between Chinese and Western Classroom Teaching}

Through comparison, we understand the strengths and weaknesses of Chinese and Western classroom teaching, and the two different teaching modes and methods cultivate people with different characteristics. Chinese and Western classroom teaching can learn from each other's strengths and make up for each other's weaknesses, because the Chinese are implicit and the Westerners are open. Own to the assiduous study of the Chinese and the creative spirit of the Westerners, the down-to-earth Chinese are combined with the romantic and imaginative Westerners. Then both Chinese and Western teaching effects will be significantly improved. Chinese teachers not only impart a lot of knowledge to students in class, but also teach them a lot of skills. Chinese teachers should pay more attention to improve the classroom active degree, let the student participate in the activity more, give the student a little more activity space, fully mobilize the student study enthusiasm, make them good at asking questions, speaking up, and being hands-on, give full play to their autonomy and creativity and explore their critical and divergent thinking. Classroom discussion in the West can give full play to students' personality and stimulate their personal potential. It can also strictly require students to master solid basic knowledge, which will make a comprehensive breakthrough in the quality of education and teaching.

\subsection{The Significance of Comparative Study}

From above we can see that western classrooms pay attention to the development of students' personality, which happens to coincide with our country's emphasis on the people-oriented concept, which is worth our thinking and reference. But western teaching also has its own insurmountable shortcomings and disadvantages, we should take the long to fill the short, absorb its essence and combined with the characteristics of Chinese students learning, and dare to carry out teaching reform and innovation. The author thinks that classroom teaching reform can be make from the following aspects:

\subsubsection{Advocacy exploratory teaching, change traditional passive teaching into active teaching}

Teachers play a role in consulting and guidance in the teaching process, breaking the bondage of the traditional teaching concept, and letting the student as the main body of the classroom. With the students for this, teachers pay attention to two-way communication and exchanges between students, allow and encourage students have different point of view. The students who hold different opinions are often given praise and encouragement. At the same time, students should be allowed to find problems by themselves, put forward problems, and guide students to independently explore and solve problems, so as to cultivate students' ability to acquire new knowledge, analyze and solve problems, as well as their ability to communicate with others.To sum up, I don't think that Chinese and Western education is simply superior to each other. They each have their own characteristics, advantages and disadvantages. We should stand in the position of transcending oneself to think about the lack of the traditional Chinese education, study and draw lessons from western education are helpful to our place, take the essence to the dregs, changing education idea, deepen the reform of the education teaching, in order to follow the world education development trend in the future,, and to train more pillars just in our country.

\subsubsection{Various teaching methods are adopted to encourage students to take the initiative to learn}

Because of the modesty and prudence of Chinese students and their silent learning characteristics, students are ashamed to open their mouths to answer or ask questions. I adopt diversified teaching means and methods, such as teacher-student discussion method, visiting teaching method, on-site teaching method, speech style, game style, etc.

At the same time, multimedia, TV, computer and other modern means are introduced into the classroom to provide students with diversified situations that can open their minds, such as training situations, exploring situational activities and performance situations, stimulating students' subjective initiative, enabling students to innovate and imagine in a broader space and time, and improving their comprehensive quality. 
1.5.3. Create equal, harmonious and happy relationship between teachers and students, and build a good learning atmosphere

Teachers should change their roles from being the leader and soloist to being the guide and accompanist in class. Change the former role of teaching high above the preaching, bending down and students sincere, equal dialogue, communication and discussion. If teachers infect and influence the students with a kind and gentle image, the students will have a sense of affinity to love learning, to create a loose, cheerful and positive teaching atmosphere. Under the influence of traditional educational thoughts such as Chinese Confucianism and Taoism, it still needs time to change the style of Chinese classroom, carry out thorough teaching reform and carry out quality teaching in a short period of time [6]. But we are encouraged by the success of current curriculum and teaching reforms in universities. As teachers, we should start from the practical teaching, cultivate respect for students' personality, teach through fun, let students be willing to learn, good at learning, so that students can truly apply what they have learned.

\section{CONCLUSION}

To sum up, Chinese and Western education each have their own characteristics, advantages and disadvantages. We should stand in the position of transcending oneself to think about current Chinese traditional education, and study and draw lessons from western education are helpful to our place, we should take the essence to the dregs, change education idea and education thoughts, deepen the reform of the education teaching. With these methods, our country's education can be improved to keep up with the trend.

\section{ACKNOWLEDGMENT}

First and foremost, I would like to show my deepest gratitude to my supervisor, Eva Chen, a respectable, responsible and resourceful scholar, who has provided me with valuable guidance in every stage of the writing of this thesis. Without her enlightening instruction, impressive kindness and patience, I could not have completed my thesis. Her keen and vigorous academic observation enlightens me not only in this thesis but also in my future study. I would also like to thank all my teachers who have helped me to develop the fundamental and essential academic competence. My sincere appreciation also goes to the teachers and students from Jiangsu University, who participated this study with great cooperation. Last but not least, I' d like to thank all my friends, especially my three lovely roommates, for their encouragement and support.

\section{REFERENCES}

[1] M. Yu, H. Guo. A Brief Analysis of the Differences between Chinese and Western Classroom Teaching Methods under educational Thinking Mode [J]. Journal of Teaching Science,200.6, (I)

[2] W. LAN. Comparison of Classroom Teaching Modes between China and Foreign countries [J]. Career Space and Time,2006, (13).

[3] D. Xu. Comparative Study of Chinese and Western Classroom Teaching [J]. Science and Technology Guide,2011, No. 92.

[4] In History and Ethics by Wei Xianchao and Wang Xiaofei. A Comparative Study of Moral Education between China and the West. Zhejiang University Press, 2009.09

[5] Z. Yuan, Reflection on Science Education, Management of Primary and Secondary Schools, 1999.12

[6] Y. Tu, Educational Evaluation, Higher Education Press, 2007 